\begin{tabular}{|l|l|l||}
\hline \multicolumn{2}{|c|}{ PublisherInfo } \\
\hline \hline PublisherName & $:$ & BioMed Central \\
\hline \hline PublisherLocation & $:$ & London \\
\hline \hline PublisherImprintName & $:$ & BioMed Central \\
\hline \hline
\end{tabular}

\title{
Modifying DiGeorge
}

\begin{tabular}{|l|l|l||}
\hline \multicolumn{2}{|c|}{ ArticleInfo } \\
\hline \hline ArticleID & $:$ & 4210 \\
\hline \hline ArticleDOI & $:$ & $10.1186 /$ gb-spotlight-20010926-02 \\
\hline \hline ArticleCitationID & $:$ & spotlight-20010926-02 \\
\hline \hline ArticleSequenceNumber & $:$ & 281 \\
\hline \hline ArticleCategory & $:$ & Research news \\
\hline \hline ArticleFirstPage & $:$ & 1 \\
\hline \hline ArticleLastPage & $:$ & 2 \\
\hline \hline & & RegistrationDate : 2001-09-26 \\
ArticleHistory & $:$ & OnlineDate \\
\hline \hline ArticleCopyright & $:$ & BioMed Central Ltd2001 \\
\hline \hline ArticleGrants & $:$ & \\
\hline \hline ArticleContext & $:$ & 130592211 \\
\hline \hline
\end{tabular}




\section{Jonathan B Weitzman}

Email: jonathanweitzman@hotmail.com

Patients with del22q11 syndrome, which includes DiGeorge and velocardiofacial syndromes, present with a range of abnormalities including cardiovascular defects, thymic and parathyroid hypoplasia, facial anomalies and mental retardation. Although most patients have a common $3 \mathrm{Mb}$ deletion within chromosome 22q11.2, their clinical symptoms are highly variable. In the September 25 Proceedings of the National Academy of Sciences, Ilaria Taddei and colleagues at the Baylor College of Medicine provide evidence for genetic modifiers that influence the phenotypic variability of del22q11 syndrome (Proc Natl Acad Sci USA 2001, 98:11428-11431). They studied a mouse model of the disease which harbours a deletion, $D f 1$, in the corresponding region of the mouse genome. They derived $D f 1$ lines on different genetic backgrounds - either a pure 129SvEv background (the genetic background of the embryonic stem cell line used to generate the mice) or on a C57BL/6 background (back-crossed for nine generations). Taddei et al. then examined the phenotypes of $D f 1 /+$ embryos on the two backgrounds. They observed a lower penetrance of cardiovascular defects on the $129 \mathrm{SvEv}$ background (16.1\%) than on the C57BL/6 background (50\%). Analysis of F1 hybrid embryos indicated that allelic variation within the haploid segment does not account for the high penetrance of defects on the C57BL/6 background. Thymic anomalies were also more frequent in the congenic C57BL/6 background $(42.5 \%)$ than in the inbred $129 \mathrm{SvEv}$ background $(11.3 \%)$, but occurred independently of cardiovascular defects.

\section{References}

1. DiGeorge syndrome, [http://www.ncbi.nlm.nih.gov/entrez/dispomim.cgi?id=188400]

2. Velocardiofacial syndrome, [http://www.ncbi.nlm.nih.gov/entrez/dispomim.cgi?id=192430]

3. Proceedings of the National Academy of Sciences, [http://www.pnas.org]

4. Baylor College of Medicine, [http://research.bcm.tmc.edu/]

5. Congenital heart disease in mice deficient for the DiGeorge syndrome region. 